\title{
POLA PENGALOKASIAN PENDAPATAN PETANI CENGKEH DI DESA KIAWA I KECAMATAN KAWANGKOAN UTARA
}

\author{
Wandi B. Lumintang \\ Juliana R. Mandei \\ Gene H.M. Kapantow
}

\begin{abstract}
The objective of this research was to understandthe allocation pattern of clove farmers' income at Kiawa 1 Village at the harvest time in 2014. This research was conducted in the Kiawa 1 Village for 3 months, from April 2015 to July 2015. Primary and secondary data were used in this research. The primary data were obtained by interviewing respondents using a list of questions (questionnaire). The secondary data were obtained from some relevant offices. Thirty respondents were randomly selected from 86 available farmers. Data were analysed descriptivelyusing some tables. The respondents were grouped based on their incomes, which were those with incomes less than 50 millions rupiahs and those with incomes of 50 millions rupiahs or above.The results showed that the income allocation pattern of the farmers' with income <50 million as follows:average consumption was Rp. 25,762,483.6 or 70.48\%, average investment was Rp. 6396533.7 or $17.50 \%$, and average savings was Rp. 4389871.4 or $12.01 \%$. Moreover, the pattern for the group of farmers with income >50 million as follows: average consumption was Rp. 46,242,699.1 or 46.67\%, average investment was $R p .27,309,599.67$ or $27.56 \%$ and average savings was $R p .25,532,689.2$ or $25.76 \%$. The results indicated that the magnitude of the farmer's income affected the income allocation for consumption, investment and savings. As the farmers' incomes increased the allocation for consumption tended to decrease while the allocation for investment and savings tended to increase. ${ }^{* g h m k} *$
\end{abstract}

Keywords: allocation, income, clove farmers, Kiawa 1 Village, North Kawangkoan Sub-district

\begin{abstract}
ABSTRAK
Penelitian ini bertujuan untuk mempelajari pola pengalokasian pendapatan petani cengkeh di Desa Kiawa I pada saat panen di Tahun 2014. Penelitian ini dilakukan di Desa Kiawa I, selama 3 bulan yaitu pada bulanapril 2015 sampai Juli 2015. Data yang diambil adalah data primer dan data sekunder. Data primer yaitu dengancara mewawancarai responden secara langsung dengan menggunakan daftar pertanyaan (kusioner). Data sekunder diperoleh langsung dari instansi-instansi terkait dengan penelitian ini. Sampel diambil sebanyak 30 petani responden dari 86 orang petani dengan menggunakan teknik simple random sampling. Data dianalisis secara deskriptif berdasarkan tabel-tabel. Berdasarkan hasil penelitian, Pendapatan petani dikelompokan menjadi, kelompok pendapatan $<50$ juta dan kelompok pendapatan $>50$ juta. Pada kelompok pendapatan petani $<50$ juta, konsumsi rata-rata sebesar Rp. 25.762.483,6 atau 70,48\% investasi rata-rata sebesar Rp. 6.396.533,7 atau $17,50 \%$ dan tabungan rata-rata sebesar Rp. 4.389.871,4 atau 12,01\%. Kelompok pendapatan petani $>50$ juta, konsumsi rata-rata sebesar Rp. 46.242.699,1 atau 46,67\%, investasi rata-rata sebesar Rp. 27.309.599,67 atau 27,56\% dan tabungan rata-rata sebesar Rp. 25.532.689,2 atau 25,76\%. Hasil penelitian ini menunjukan bahwa, besarnya pendapatan petani mempengaruhi alokasi pendapatan petani untuk konsumsi, investasi dan tabungan. Kelompok pendapatan petani <50 juta, investasi dan tabungan petani relative sedikit dikarenakan konsumsi yang tinggi, sedangkan kelompok pendapatan petani >50 juta, pengeluaran untuk kebutuhan konsumsi menurun sedangkan invetasi dan tabungan menjadi bertambah.
\end{abstract}

Kata kunci: alokasi, pendapatan, petani cengkeh, Desa Kiawa I, Kecamatan Kawangkoan Utara 


\section{PENDAHULUAN}

\section{Latar belakang}

Indonesia merupakan negara berkembang dengan sektor pertanian sebagai mata pencaharian dari mayoritas penduduknya. Dengan demikian, sebagian besar penduduknya menggantungkan hidupnya pada sektor pertanian.Pertanian dalam arti luas meliputi sector pertanian, perikanan, peternakan dan perkebunan. Sedangkan dalam arti sempit pertanian diartikan sebagai kegiatan bercocok tanaman (Mubyarto, 1995).

Sektor pertanian merupakan sektor yang mendapatkan perhatian cukup besar dari pemerintah dikarenakan peranannya yang sangat penting dalam rangka pembangunan ekonomi jangka panjang maupun dalam rangka pemulihan ekonomi bangsa. Hal ini terlihat dari peranan sektor pertanian terhadap penyediaan lapangan kerja, penyediaan pangan, penyumbang devisa Negara melalui ekspor dan sebagainya (Soekartawi, 1995).

Sulawesi Utara adalah daerah yang sebagian besar penduduknya bergantung dari sektor pertanian, sehingga pendapatan penduduk juga berasal dari sektor pertanian. Daerah ini juga merupakan daerah pengahasil produk pertanian yaitu tanaman hortikultura, tanaman pangan dan tanaman perkebunan. Salah satu tanaman perkebunan yang dihasilkan di daerah ini adalah tanaman cengkeh. Tanaman cengkeh (Sygzgium aromaticum) adalah salah satu tanaman perkebunan yang sebagian besar merupakan perkebunan rakyat. Hasil tanaman cengkeh yang diperdagangkan terutama untuk bahan baku industri rokok kretek, kosmetik, dan juga digunakan sebagai bahan dasar pembuatan obat-obatan. (Plantus, 2008). Nilai ekonominya yang tinggi merupakan factor mengapa tanaman ini banyak di budidayakan masyarakat. Selain untuk meningkatkan ekonomi pelaku usahatani cengkeh, pentingnya usahatani cengkeh ini bagi masyarakat juga dilihat dari perananya sebagai penyedia lapangan kerja.

Desa Kiawa 1 Kecamatan Kawangkoan Utara adalah Desa yang telah dimekarkan saat ini menjadi tiga Desa yaitu Desa Kiawa I, Kiawa I Barat, Kiawa I Utara. Sebagian besar masyarakatnya berprofesi sebagai petani cengkeh dan merupakan sumber mata pencaharian masyarakat. Hal ini terbukti bahwa luas lahan dan produksi cengkeh di Kecamatan Kawangkoan Utara Desa Kiawa I menjadi Desa yang memiliki luas lahan dan produksi yang paling tinggi di Kecamatan Kawangkoan Utara.

\section{Tabel 1. Luas Lahan Dan Produksi Perkebunan Cengkeh Di Kecamatan Kawangkoan Utara}

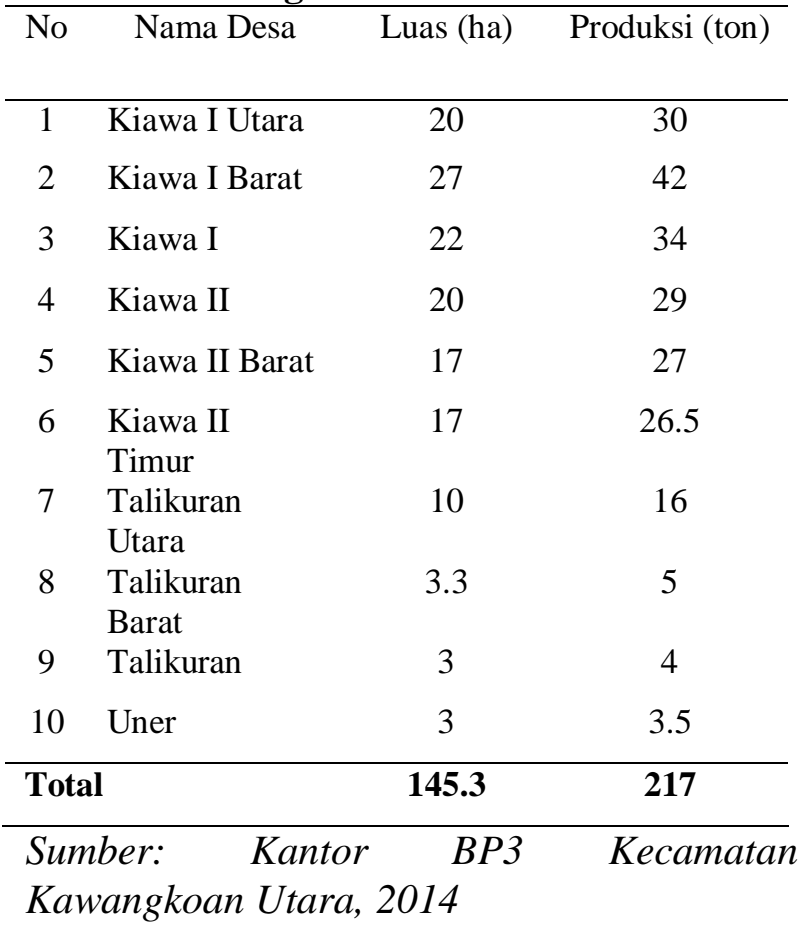

Selain dibudidayakan di Desa Kiawa I, untuk menambah produksi, umumnya petani cengkeh menambah luas lahan perkebunan cengkeh mereka dengan membeli lahan perkebunan di Desa lain yang merupakan daerah komoditi cengkeh. Tujuan petani cengkeh ini adalah untuk meningkatkan produksi dan pendapatan yang di terimanya.

Pendapatan merupakan indikator untuk mengukur kesejahteraan masyarakat sehingga pendapatan mencerminkan kemajuan ekonomi masyarakat. Untuk menilai kesejatraan ekonomi 
rumah tangga petani perlu mengetahui mengenai pola konsumsi rumah tangga petani. Dalam arti alokasi untuk kebutuhan primer, sekunder dan tersier. Tingkat kesejatraan suatu masyarakat membaik apabila pendapatan meningkat dan alokasi konsumsi masyarakat mengalami pergeseran kebutuhan dari kebutuhan primer ke sekunder dan tersier. Pendapatan rumah tangga petani amat besar pengaruhnya terhadap alokasi konsumsi rumah tangga petani. Menurut teori Keynesian besarnya konsumsi sektor rumah tangga dalam perekonomian tergantung dari besarnya pendapatan. Jumlah pendapatan yang diterima setiap rumah tanggga petani tidak sama besarnya satu dengan yang lainya. Perbedaan pendapatan petani tersebut menimbulkan perbedaan-perbedaan mengenai pola pengalokasian pendapatan rumah tangga petani. Petani yang berpenghasilan rendah cenderung mengalokasikan pendapatanya untuk memenuhi kebutuhan-kebutuhan dasar saja seperti makanan, pakaian dan tempat tinggal. Apabila pendapatan petani meningkat porsi pendapatan untuk kebutuhan dasar akan menurun sebaliknya alokasi pendapatanya cenderung ke kebutuhan tersier.

Melihat harga komoditi cengkeh yang beberapa tahun belakangan ini berada di harga yang tinggi menjadikan pendapatan rumah tangga petani cengkeh di Desa Kiawa I meningkat. Perubahan pendapatan ini tentunya membawa perubahan mengenai pola pengalokasian pendapatan petani cengkeh di Desa Kiawa I. Dengan selesainya panen di tahun 2014 diikuti dengan kenaikan harga komoditi cengkeh menjadikan hal tersebut sangat menarik untuk di lakukan penelitian mengenai pola pengalokasian pendapatan petani cengkeh di Desa Kiawa I.

\section{Rumusan Masalah}

Berkaitan dengan latar belakang penelitian diatas, maka dirumuskan suatu permasalahan untuk diteliti yaitu; Bagaimanakah pola pengalokasian pendapatan yang dilakukan oleh petani cengkeh di Desa Kiawa I?

\section{Tujuan Penelitian}

Penelitian ini bertujuan untuk mendeskripsikan pola pengalokasian pendapatan petani cengkeh di Desa Kiawa I pada musim panen tahun 2014.

\section{Manfaat Penelitian}

Penelitian ini diharapkan dapat memberikan informasi lebih lanjut tentang pola pemanfaatan pendapatan petani cengkeh dan bahan pertimbangan dalam merencanakan pembangunan pertanian di pedesaan.

\section{METODELOGI PENELITIAN}

\section{Waktu Dan Lokasi Penelitian}

Penelitian ini berlangsung selama 3 bulan sejak dari persiapan sampai penyusunan laporan yaitupada bulan April 2015 sampai Juli 2015. Penelitian ini berlokasi di Desa Kiawa I, Kiawa I Barat, Kiawa I Utara, Kecamatan Kawangkoan Utara.

\section{Metode Pengumpulan Data}

Penelitian ini menggunakan metode survey. Dimana data yang diambil adalah data primer dan data sekunder. Data primer yaitu dengan cara mewawancarai responden secara langsung dengan menggunakan daftar pertanyaan (kusioner) yang telah disiapkan terlebih dahulu. Sedangkan data sekunder diperoleh langsung dari instansi-instansi terkait dengan penelitian ini.

\section{Metode Pengambilan Sampel}

Metode pengambilan sampel dalam penelitian ini adalah menggunakan simple random sampling. Jumlah petani yang akan diteliti dalam penelitian ini adalah sebanyak 30 petani responden yang mengalami panen cengkeh di tahun 2014. Jumlah populasi adalah 86 petani. 


\section{Konsep Pengukuran Variabel}

Variable-variabel yang di ukur:

1. Penerimaan adalah jumlah produksi dari usahatani cengkeh, non-cengkeh dan nonusahatani yang dihitung dalam satu tahun dikalikan dengan harga jual yang dinyatakan dalam satuan rupiah (Rp).

2. Pengeluaran adalah biaya yang dikeluarkan selama proses produksi berlangsung, terdiri dari 3 sumber yaitu:

a. Usahatani cengkeh (biaya produksi) yaitu terdiri atas:

Biaya tenaga kerja, Biaya selama panen Biaya angkutan, biaya penyusutan alat dan pajak (Rp).

b. Usahatani non-cengkeh yang terdiri atas

Biaya tenaga kerja, pestisida, giling, angkutan (Rp).

c. Non-usahatani seperti ternak babi dan usaha.

3. Pendapatan usaha tani cengkeh adalah total dari penerimaan usahatani cengkeh dikurangi pengeluaran usahatani cengkeh (total biaya) $(\mathrm{Rp} /)$.

4. Pendapatan petani dari sumber lain yaitu total pendapatan yang diperoleh petani dari sumber lain diluar usahatani cengkeh (Rp).

5. Pendapatan total petani cengkeh adalah jumlah keseluruhan pendapatan yang diperoleh petani dari usahatani cengkeh dan pendapatan dari sumber lain $(\mathrm{Rp})$.

6. Pola pengalokasian pendapatan petani cengkeh kedalam berbagai kegiatan yaitu:

a. Konsumsi keluarga yaitu jumlah pendapatan yang dialokasikan untuk kebutuhan konsumsi antara lain untuk kebutuhan primer, sekunder dan kebutuhan tersier (Rp/tahun).

b. Tabungan yaitu besarnya uang yang ditabung petani (Rp/tahun).

c. Investasi, yaitu besarnya uang yang dialokasikan untuk kegiatan investasi yang dilakukan oleh keluarga petani(Rp/tahun).

Dari kegiatan-kegiatan yang dilakukan oleh petani akan dilihat persentase penggunaan pendapatan masing-masing kegiatan konsumsi, tabungan, dan investasi (\%). Selain variabelvariabel diatas juga akan dilihat variabel umur, pendidikan, jumlah tanggungan dari responden.

\section{Metode Analisis Data}

Sesuai dengan permasalahan dan tujuan yang akan dicapai maka analisis data yang digunakan adalah analisis secara deskriptif berdasarkan data yang disajikan dalam tabletabel.

\section{HASIL DAN PEMBAHASAN}

\section{Deskripsi Wilayah Penelitian}

Desa Kiawa I adalah Desa yang telah dimekarkan Menjadi Kiawa Satu, Kiawa Satu Barat, Kiawa Satu Utara dan berada di Kecamatan Kawangkoan Utara Kabupaten Minahasa, yang berjarak $1 \mathrm{Km}$ dari ibukota Kecamatan dan $20 \mathrm{Km}$ dari ibukota Kabupaten dengan luas wilayah Desa Kiawa 227 ha, Kiawa 1 Barat 283 ha Kiawa 1 Utara 242 ha .memiliki 3 lingkungan (Jaga) tiap-tiap desa. Desa Kiawa 1 memiliki batas-batas wilayah sebagai berikut:

1. Sebelah Utara berbatasan dengan Kecamatan Sonder

2. Sebelah Timur berbatasan dengan Desa Kiawa Dua

3. Sebelah Selatan berbatasan dengan Kecamatan Kawangkoan Barat

4. Sebelah Barat berbatasan dengan Kecamatan Tareran.

\section{Jumlah Penduduk}

Jumlah penduduk Desa Kiawa 1 sampai dengan tahun 2014 ini, Kiawa 1518 jiwa terdiri dari laki-laki 327, perempuan 191, Kiawa 1 Barat, 610 jiwa terdiri dari 273 laki-laki 345 perempuan, Kiawa 1 Utara 530 jiwa terdiri dari 320 laki-laki dan 210 perempuan.

\section{Mata Pencaharian}

Sumber mata pencaharian yang utama penduduk Desa Kiawa 1 terdiri dari sektor formal dan informal yaitu sebagai Petani, PNS, Polri, Tukang, Wiraswasta, Sopir, Pensiunan dan lain-lain. Mata pencaharian petani dapat dilihat pada Tabel 2.

Tabel 2 menunjukan, baik Kiawa I, Kiawa I Barat, Kiawa I Utara, petani merupakan profesi yang paling banyak dijalankan petani. Kiawa I sebanyak 97 orang, Kiawa I Barat 150 orang, Kiawa I Utara 130 orang. 


\section{Karakteristik Responden Umur}

Umur sangat memperngaruhi kemampuan seseorang untuk berkerja secara fisik dan menentukan cara berfikir. Secara umum dapat dikatakan bahwa semakin tinggi umur seseorang maka produktivitasnya untuk berkerja semakin berkurang, karena pada dasarnya petani yang berumur muda lebih kuat di bandingkan denganpetani yang berumur lebih tua. Untuk lebih jelas mengenai umur responden dapat di lihat pada Tabel 3.

Dari Tabel 3 dapat dilihat bahwa petani yang berumur $38-48$ tahun ada sebanyak 8 orang atau $30 \%$. Petani yang berumur 49-59 tahun sebanyak 17 orang atau $56,66 \%$ dan petani yang berumur $60>$ sebanyak 4 orang atau $13,33 \%$, pada golongan umur 60> tahun, kondisi fisik dan kemampuan bekerja menurun, akibatnya segala kegiatan yang menyangkut dengan usahatani cengkeh lebih memerlukan tenaga kerja dari luar keluarga.

\section{Tingkat Pendidikan}

Pendidikan merupakan kebutuhan pokok bagi setiap anggota masyarakat dalam peningkatan sumber daya manusia. Pendidikan mempengaruhi seseorang dalam menentukan sikap, peningkatan intelektual dan bahkan dalam hal pengambilan keputusan untuk mengelolah usahataninya. Semakin tinggi tingkat pendidikan seorang petani maka semakin mudah menerima masukkan dan saran dalam mengelolah usahatani. Tingkat pendidikan petani responden dapat di lihat pada Tabel 4.

Tabel 4 menunjukan bahwa tingkat pendidikan formal petani cengkeh 12 Orang atau $40 \%$ berpendidikan SMA sedangkan petani yang berpendidikan SD dan SMP jumlahnya sama yaitu SD 9 orang atau 30\% dan SMP 9 orang atau $30 \%$. Hal ini menunjukan tingkat pendidikan petani cengkeh cukup baik. Begitupun dengan cara petani mengelolah usahtani cengkeh dengan cukup baik.

\section{Jumlah Tanggungan Keluarga}

Jumlah anggota keluarga rumah tangga merupakan semua orang yang tinggal didalam atau diluar rumah yang masih menjadi tanggungan kepala rumah tangga terdiri dari responden itu sendiri, isteri, anak-anak. Jumlah anggota rumah tangga berpengaruh terhadap pengeluaran untuk pangan, pakaian serta kebutuhan lainnya. Jumlah tanggungan keluarga dapat dilihat pada Tabel 5.

Tabel 5 menjelaskan bahwa petani yang memiliki jumlah tanggungan keluarga 2 orang sebanyak 12 petani atau $40 \%$, jumlah tanggungan 3 orang sebanyak 11 petani atau $36,66 \%$ dan golongan yang memiliki jumlah tanggungan lebih dari 4 orang sebanya 7 petani responden atau $23,33 \%$.

\section{Penerimaan}

Penerimaan adalah harga dikali produksi. Penerimaan yang dimaksud dalam penelitian ini adalah penerimaan yang diterima petani dari usahatani cengkeh, usahatani non cengkeh (usahatani lain) maupun dari kegiatan nonusahatani. Untuk melihat rata-rata penerimaan rumah tangga petani dapata dilihat pad Tabel 6 .

Tabel 6 menunjukan rata-rata jumlah penerimaan petani berdasarkan kelompok pendapatan petani $<50$ juta dan kelompok pendapatan petani $>50$ juta. Rata-rata total penerimaan kelompok pendapatan petani $<50$ juta sebesar Rp. 65.464.222,47 dan pada kelompok pendapatan petani $>50$ juta sebesar Rp.148.944.000.Usahatani cengkeh merupakan penerimaan paling tinggi yaitu pada kelompok pendapatan petani $<50$ juta rata-rata sebesar Rp.43.953.666,67 atau 67,14\% dan pada kelompok pendapatan petani $>50$ juta sebesar Rp. 131.000 .000 atau $87,95 \%$. Berdasarkan penelitian produksi dan harga cengkeh yang tinggi menjadikan penerimaan dari usahatani cengkeh lebih tinggi dari usahatani lain dan non-usahatani.

\section{Biaya Produksi}

Biaya produksi adalah keseluruhan biaya yang di keluarkan petani yang terdiri dari biaya tetap dan biaya tidak tetap. Biaya produksi yaitu semua biaya yang dikeluarkan atau digunakan pada kegiatan usahatani cengkeh, kegiatan usahatani lain dan non-usahatani. Untuk melihat rata-rata biaya produksi usahatani cengkeh, usahatani lain dan non usahatani dapat dilihat pada Tabel 7. 
Tabel 7 menunjukan rata rata biaya produksi yang dikeluarkan petani berdasarkan kelompok pendapatan petani $<50$ juta dan kelompok pendapatan petani $>50$ juta. Rata-rata biaya produksi pada kelompok pendapatan petani $<50$ juta sebesar Rp. 28.915.333,8 dan pada kelompok pendapatan petani $>50$ juta sebesar Rp.49.859.012.

Berdasarkan hasil penelitian, usahatani cengkeh merupakan biaya produksi paling tinggi yaitu pada kelompok pendapatan petani $<50$ juta rata-rata sebesar 20.739.011,47 atau $71,72 \%$ dan pada kelompok pendapatan petani >50 juta rata-rata sebesar Rp. 42.628.556,13 atau $85,51 \%$. Dari hasil wawancara dengan responden bahan makanan dan upah buruh merupakan biaya yang paling tinggi.

\section{Pendapatan}

Pendapatan total rumah tangga petani cengkeh terdiri dari seluruh pendapatan yang di peroleh dari usahatani cengkeh, usahatani lain maupun non-usahatani. Untuk mengetahui rata-rata total pendapatan petani dapat dilihat pada Tabel 8 .

Tabel 8 menunjukan rata-rata pendapatan petani berdasarkan kelompok pendapatan petani, pendapatan $<50$ juta rata-rata pendapatan sebesar Rp.36.548.888,7 dan kelompok pendapatan petani $>50$ juta rata-rata sebesar Rp.99.084.988. Ratarata persentase pendapatan petani yang paling tinggi yaitu pada usahatani cengkeh yaitu pada kelompok pendapatan petani $<50$ juta rata-rata sebesar Rp.23.214.655,2 atau 65,64\% dan pada kelompok pendapatan petani $>50$ juta rata-rata

sebesar Rp. 88.545.688,9 atau 89,09\%. Ternak babi merupakan sumber pendapatan ke 2 tertinggi yaitu pada kelompok pendapatan petani $<50$ juta rata-rata sebesar Rp. 10.013.333,33 atau $25,79 \%$ dan kelompok pendapatan petani $>50$ juta rata-rata sebesar Rp. 7.113.333,3 atau 7,36\%.

Dari hasil penelitian dari beberapa kegiatan yang di lakukan petani, berternak babi merupakan kegiatan yang banyak di lakukan petani untuk menambah pendapatan selama menunggu panen cengkeh.

\section{Alokasi Pendapatan Keluarga Petani Untuk Konsumsi}

Alokasi untuk kebutuhan konsumsi adalah pengeluaran pada saat untuk memenuhi kebutuhan pada saat itu. Pengertian lain dari alokasi pendapatan untuk kebutuhan konsumsi adalah semua dana atau pendapatan yang digunakan untuk konsumsi terdiri dari kebutuhan primer yaitu (makanan, airminum, pakaian perbaikan rumah/baru) kebutuhan sekunder (lpg kesehatan, listrik, transportasi rekreasi kegiatan social/keagamaan) kebutuhan tersier (biaya pesta, prabot/alat elektronik, parabol/kabel tv, sepeda motor/mobil, pulsa/rokok). Rata-rata pengeluaran untuk alokasi keluarga petani untuk konsusmi dapat dilihat pada Tabel 9.

Tabel 9 menunjukan rata- rata pengeluaran berbagai kegiatan konsumsi berdasarkan kelompok pendapatan petani $<50$ juta dan kelompok pendapatan petani $>50$ juta. Kelompok pendapatan $<50$ juta, rata-rata total pengeluaran untuk konsumsi sebesar Rp.25.762.483,6 dan kelompok pendapatan petani yaitu $>50$ juta ratarata sebesar Rp. 46.242.699,1. Hal ini menunjukan bahwa semakin besar pendapatan petani maka pengeluaran konsumsi juga semakin besar.

Penelitian ini juga membuktikan bahwa besarnya pendapatan mempengaruhi setiap kegiatan konsumsi petani. Kelompok pendapatan petani $<50$ juta, jumlah pengeluran konsumsi untuk kebutuhan primer cenderung lebih tinggi yaitu sebesar Rp. 14.894.800, atau 57,81\% dari total pengeluaran konsumsi, sedangkan pada kelompok pendapatan $>50$ juta, pengeluaran untuk kebutuhan primer sebesar Rp. 16.957.733, atau $36,67 \%$, menurun dari total pengeluaran konsumsi. Hal ini membuktikan bahwa pada pendapatan yang rendah jumlah pengeluaran lebih ke kebutuhan dasar/primer dan apabilapendapatan meningkat pengeluaran untuk kebutuhan dasar/primer menurun dan kebutuhan sekunder dan tersier meningkat.

\section{Alokasi Pendapatan Keluarga Petani Untuk Investasi}

Yang dimaksud dengan alokasi untuk investasi adalah semua dana atau pendapatan yang digunakan petani cengkeh untuk investasi yang terdiri dari pendidikan, membeli kebun, pembelian tanah, mobil angkutan, pengembangan usaha, dan perhiasan. Singkatnya alokasi pendapatan untuk investasi adalah pengeluaran pada suatu saat untuk memenuhi kebutuhan pada waktu yang akan datang. Untuk melihat rata- 
rata jumlah investasi dapat dilihat pada Tabel 10.

Tabel 10 menunjukan rata-rata pengeluaran investasi yang dilakukan petani berdasarkan kelompok pendapatan petani $<50$ Juta dan $>50$ juta, jumlah pendapatan mempengaruhi alokasi untuk investasi. Petani yang memiliki pendapatan lebih rendah yaitu $<50$ juta rata-rata investasi sebesar Rp.6.396.533,7, sedangkan petani yang memiliki pendapatan $>50$ juta lebih banyak melakukan investasi yaitu rata-rata sebesar Rp.27.309.599,67. Dari hasil wawancara dengan petani kenaikan harga cengkeh yang diikuti kenaikan pendapatan petani, mendorong petani untuk melakukan beberapa kegiatan investasi.

Investasi paling tinggi diinvestasikan untuk kegiatan produksi dengan membeli kebun cengkeh yaitu pada kelompok pendapatan petani $<50$ juta investasi untuk membeli kebun cengkeh rata-rata sebesar Rp. 2.000 .000 atau 31,26\% dan pada kelompok pendapatan petani $>50$ juta ratarata sebesar Rp. 9.133 .333 atau 33,44\%, kegiatan investasi ini diharapkan bisa menambah produksi cengkeh pada panen berikuntya.

\section{Alokasi Pendapatan Keluarga Petani Untuk Tabungan}

Tabungan adalah simpanan uang, merupakan bagian dari pendapatan yang tidak dikonsumsikan/pendapatan yang disishkan dari keperluan konsusmsi. Baik Dalam bentuk Tabungan di Bank maupun berupa arisan.

Rata-rata tabungan kelompok pendapatan petani $<50$ juta sebesar Rp.4.389.871,4 dan ratarata tabungan kelompok pendapatan petani $>50$ juta sebesar Rp.25.532.689,2. Hal ini menunjukan bahwa besarnya pendapatan mempengaruhi tabungan petani, semakin tinggi pendapatan semakin besar tabungan petani.

\section{Rekapitulasi Alokasi Pendapatan Rumahtangga Petani}

Tabel 11 menunjukan rekapitulasi alokasi pendapatan petani cengkeh di Desa Kiawa 1, Pada kelompok pendapatanyaitu $<50$ juta, konsumsi rata-rata sebesar Rp. 25.762.483,6 atau 70,48\% investasi sebesar Rp. 6.396.533,7 atau 17,50\% dan tabungan Rp. 4.389.871,4 atau $12,01 \%$. Kelompok pendapatan petani $>50$ juta, konsumsi rata-rata sebesar Rp. 46.242.699,1 atau 46,67\%, investasi sebesar Rp. 27.309.599,67 atau 27,56\% dan tabungan sebesar Rp. 25.532.689,2 atau $25,76 \%$. Hasil penelitian ini menunjukan bahwa, besarnya pendapatan petani mempengaruhi alokasi pendapatan petani untuk konsumsi, investasi dan tabungan. Kelompok pendapatan petani yang lebih rendah yaitu <50 juta, investasi dan tabungan petani relative sedikit dikarenakan konsumsi yang tinggi, sedangkan kelompok pendapatan petani yang lebih besar yaitu $>50$ juta, pengeluaran untuk kebutuhan konsumsi menurun dan investasi dan tabungan menjadi bertambah.

Tabel 2. Mata Pencaharian

\begin{tabular}{llccc}
\hline No. & Profesi & Desa Kiawa I & Desa Kiawa I barat & Desa kiawa I utara \\
\hline 1 & Petani & 97 & 150 & 130 \\
2 & Buruh tani & 7 & 30 & 36 \\
3 & Guru & 3 & 4 & 5 \\
4 & Pns & 5 & 3 & 6 \\
5 & Pegawai swasta & 2 & 6 & 8 \\
6 & Tni /polri & - & - & - \\
7 & Pesiunan & 5 & 4 & 3 \\
8 & Peternak & 54 & 60 & 50 \\
9 & Wiraswasta & 42 & 50 & 47 \\
10 & Tukang & 18 & 24 & 15 \\
11 & Sopir & 14 & 7 & 5 \\
12 & Pedagang & 7 & 20 & 18 \\
13 & Tukang ojek & 15 & 376 & 340 \\
\hline
\end{tabular}

Sumber: Kantor Desa Kiawa 1, Kiawa 1 Barat, Kiawa 1 Utara. 2014 
Tabel 3. Jumlah Dan Persentase Petani Menurut Golongan Umur

\begin{tabular}{cccc}
\hline No & $\begin{array}{c}\text { Umur } \\
(\text { Tahun })\end{array}$ & $\begin{array}{c}\text { Petani Responden } \\
\text { (Orang) }\end{array}$ & $\begin{array}{c}\text { Persentase } \\
(\%)\end{array}$ \\
\hline 1 & $38-48$ & 9 & 30 \\
2 & $49-59$ & 17 & 56,66 \\
3 & $60>$ & 4 & 13,33 \\
\hline Total & & $\mathbf{3 0}$ & $\mathbf{1 0 0}$ \\
\hline
\end{tabular}

Tabel 4. Jumlah Dan Persentase Petani Menurut Tingkat Pendidikan

\begin{tabular}{cccc}
\hline No & Pendidikan & $\begin{array}{c}\text { Petani Responden } \\
\text { (Orang) }\end{array}$ & $\begin{array}{c}\text { Persentase } \\
(\%)\end{array}$ \\
\hline 1 & SD & 9 & 30 \\
2 & SMP & 9 & 30 \\
3 & SMA & 12 & 40 \\
\hline Total & & $\mathbf{3 0}$ & $\mathbf{1 0 0}$ \\
\hline
\end{tabular}

Tabel 5. Jumlah Dan Persentase Petani Menurut Jumlah Tanggungan Keluarga

\begin{tabular}{rccc}
\hline No & $\begin{array}{c}\text { Jumlah Tanggungan } \\
\text { (Orang) }\end{array}$ & $\begin{array}{c}\text { Jumlah Responden } \\
\text { (Orang) }\end{array}$ & $\begin{array}{c}\text { Persentase } \\
(\%)\end{array}$ \\
\hline 1 & 2 & 12 & 40 \\
2 & 3 & 11 & 36,66 \\
3 & $4>$ & 7 & 23,33 \\
\hline Total & & $\mathbf{3 0}$ & $\mathbf{1 0 0}$ \\
\hline
\end{tabular}

Tabel 6. Rata-Rata Penerimaan Petani Dari Usahatani Cengkeh, Usahatani Lain Dan Non-Usahatani

\begin{tabular}{cccccc}
\hline No & Sumber penerimaan & $\begin{array}{c}\text { Pendapatan } \\
<50 \text { Juta }\end{array}$ & $\%$ & $\begin{array}{c}\text { Pendapatan } \\
>50 \text { Juta }\end{array}$ & $\%$ \\
\hline 1 & Usahatani cengkeh & $43.953 .666,67$ & 67,14 & 131.000 .000 & 87,95 \\
2 & Usahatani lain & & & & \\
& a. Jagung & 2.024 .667 & 3,09 & 2.597 .333 & 1,74 \\
& b. Padi sawah & $422.333,3$ & 0,64 & $653.333,3$ & 0,43 \\
& Non-Usahatani & & & & \\
& a. Ternak babi & 14.580 .000 & 22,27 & 10.426 .667 & 7,01 \\
& b. Usaha & $4.483 .555,5$ & 6,84 & $4.266 .666,7$ & 2,86 \\
\hline & Total & $\mathbf{6 5 . 4 6 4 . 2 2 2 , 4 7}$ & $\mathbf{1 0 0}$ & $\mathbf{1 4 8 . 9 4 4 . 0 0 0}$ & $\mathbf{1 0 0}$ \\
\hline
\end{tabular}


Tabel 7. Rata-Rata Biaya Produksi Usahatani Cengkeh, Usahatani Lain Dan Non-Usahatani

\begin{tabular}{|c|c|c|c|c|c|}
\hline No. & Sumber pendapatan & $\begin{array}{l}\text { Pendapatan } \\
<50 \text { Juta }\end{array}$ & $\%$ & $\begin{array}{l}\text { Pendapatan } \\
>50 \text { Juta }\end{array}$ & $\%$ \\
\hline 1 & Usahatani cengkeh & $20.739 .011,47$ & 71,72 & $42.628 .556,13$ & 85,51 \\
\hline \multirow[t]{3}{*}{2} & Usahatani lain & & & & \\
\hline & a. Jagung & $877.166,8$ & 3.03 & 1.082 .922 & 2,17 \\
\hline & b. Padi sawah & $160.933,3$ & 0,55 & $367.533,3$ & 0,73 \\
\hline \multirow[t]{4}{*}{3} & Non-Usahatani & & & & \\
\hline & a. Ternak babi & 4.566 .667 & 15,79 & 3.313 .333 & 6,64 \\
\hline & b. Usaha & 2.571 .556 & 8,89 & 2.466 .667 & 4,94 \\
\hline & Total & 28.915.333,8 & 100 & 49.859 .012 & 100 \\
\hline
\end{tabular}

Tabel 8. Rata-Rata Pendapatan Petani (Rp)

\begin{tabular}{cccccc}
\hline No & Sumber Pendapatan & $\begin{array}{c}\text { Pendapatan } \\
<50 \text { Juta }\end{array}$ & $\%$ & $\begin{array}{c}\text { Pendapatan } \\
>50 \text { Juta }\end{array}$ & $\%$ \\
\hline 1 & Usahatani cengkeh & $23.214 .655,2$ & 65,64 & $88.545 .688,9$ & 89,09 \\
2 & Usahatani lain & & & & \\
& a. Jagung & $1.147 .499,8$ & 2,95 & $1.340 .166,4$ & 1,38 \\
& b. Padi sawah & 261.400 & 0,67 & 285.800 & 0,29 \\
& Non-usahatani & & & & \\
& a. Ternak babi & $10.013 .333,33$ & 25,79 & $7.113 .333,3$ & 7,36 \\
& b. Usaha & 1.912 .000 & 4,92 & 1.800 .000 & 1,86 \\
\hline
\end{tabular}


Tabel 9. Rata-Rata Jumlah Alokasi Pendapatan Keluarga Petani Untuk Konsumsi

\begin{tabular}{|c|c|c|c|c|c|}
\hline No & Alokasi konsumsi & $\begin{array}{l}\text { Pendapatan } \\
<50 \text { Juta }\end{array}$ & $\%$ & $\begin{array}{l}\text { Pendapatan } \\
>50 \text { Juta }\end{array}$ & $\%$ \\
\hline \multirow[t]{9}{*}{1} & Kebutuhan primer & & & & \\
\hline & a. Makanan & 8.282 .800 & 32,15 & 8.687 .133 & 18,78 \\
\hline & b. Air minum & $133.733,3$ & 0,51 & $133.866,7$ & 0,28 \\
\hline & c. Pakaian & 2.409 .600 & 9,35 & 2.722 .000 & 5,88 \\
\hline & $\begin{array}{l}\text { d. Perbaikan } \\
\text { rumah/baru }\end{array}$ & $986.666,7$ & 3,82 & 2.578 .000 & 5,57 \\
\hline & e. Lpg & $746.733,3$ & 2,89 & $657.066,7$ & 1,42 \\
\hline & f. Kesehatan & 1.433 .067 & 5,56 & 1.230 .000 & 2,65 \\
\hline & g. Listrik & 902.200 & 3,50 & $949.666,7$ & 2,05 \\
\hline & Sub total & $14.894 .800,3$ & 57,81 & 16.957.733,1 & 36,67 \\
\hline \multirow[t]{5}{*}{2} & Kebutuhan sekunder & & & & \\
\hline & a. Transportasi & 1.420 .333 & 5,51 & 1.685 .600 & 3,64 \\
\hline & b. Rekreasi & 880.400 & 3,41 & 1.279 .667 & 2,76 \\
\hline & $\begin{array}{ll}\text { c. } & \text { Kegiatan } \\
\text { social/keagamaan }\end{array}$ & 1.972 .267 & 7,65 & 2.795 .333 & 6,04 \\
\hline & Sub total & 4.273.000 & 16,58 & 5.760 .600 & 12,45 \\
\hline \multirow[t]{7}{*}{3} & Kebutuhan tersier & & & & \\
\hline & a. Biaya pesta & 1.500 .000 & 5,82 & 2.400 .000 & 5,19 \\
\hline & $\begin{array}{l}\text { b. Prabot/alat } \\
\text { elektronik }\end{array}$ & 1.651 .128 & 6,40 & 4.437 .600 & 9,59 \\
\hline & c. Parabol/tv kabel & 840.060 & 3,26 & 1.020 .000 & 2,20 \\
\hline & d. Pulsa/rokok & 2.070 .162 & 8,03 & 2.633 .433 & 5,69 \\
\hline & $\begin{array}{l}\text { e. Sepeda } \\
\text { motor/mobil }\end{array}$ & $533.333,3$ & 2,07 & 13.033 .333 & 28,18 \\
\hline & Sub total & 6.594.683,3 & 25,59 & 23.524.366 & $\mathbf{5 0 , 8 7}$ \\
\hline Total & & $25.762 .483,6$ & 100 & 46.242.699,1 & 100 \\
\hline
\end{tabular}

Tabel 10. Rata-Rata Alokasi Pendapatan Keluarga Petani Untuk Investasi

\begin{tabular}{cccccc}
\hline No & Jenis investasi & $\begin{array}{c}\text { Pendapatan } \\
<50 \text { juta }\end{array}$ & $\%$ & $\begin{array}{c}\text { Pendapatan } \\
>50 \text { juta }\end{array}$ & $\%$ \\
\hline 1 & Pendidikan & 1.929 .867 & 30,17 & 5.196 .267 & 19,03 \\
2 & Kebun cengkeh & 2.000 .000 & 31,26 & 9.133 .333 & 33,44 \\
3 & Sebidang tanah & 1.800 .000 & 28,14 & 4.333 .333 & 15,87 \\
4 & Mobil angkutan & - & & 6.333 .333 & 23,19 \\
5 & Membuka usaha & $666.666,7$ & 10,42 & 1.666 .667 & 6,103 \\
6 & Perhiasan & - & & 646.666 .67 & 2,368 \\
\hline & Total & $\mathbf{6 . 3 9 6 . 5 3 3 , 7}$ & $\mathbf{1 0 0}$ & $\mathbf{2 7 . 3 0 9 . 5 9 9 . 6 7}$ & $\mathbf{1 0 0}$ \\
\hline
\end{tabular}


Tabel 11. Rekapitulasi Alokasi Pendapatan

\begin{tabular}{rrrrrrr}
\hline No. & Jenis Alokasi & $\begin{array}{c}\text { Pendapatan } \\
<50 \text { juta }\end{array}$ & $\%$ & $\begin{array}{c}\text { Pendapatan } \\
>50 \text { juta }\end{array}$ & \\
\hline 1 & Konsumsi & $25.762 .483,6$ & 70,48 & $46.242 .699,1$ & 46,67 \\
2 & Investasi & $6.396 .533,7$ & 17,50 & $27.309 .599,67$ & 27,56 \\
3 & Tabungan & $4.389 .871,4$ & 12,01 & $25.532 .689,2$ & 25,76 \\
\hline & & $\mathbf{3 6 . 5 4 8 . 8 8 8 , 7}$ & $\mathbf{1 0 0}$ & $\mathbf{9 9 . 0 8 4 . 9 8 8}$ & $\mathbf{1 0 0}$ \\
\hline
\end{tabular}

\section{KESIMPULAN DAN SARAN}

\section{Kesimpulan}

Berdasarkan hasil penelitian. Pada kelompok pendapatan petani $<50$ juta, konsumsi rata-rata sebesar Rp. 25.762.483,6 atau 70,48\% investasi sebesar Rp. 6.396.533,7 atau $17,50 \%$ dan tabungan Rp. 4.389.871,4 atau $12,01 \%$. Kelompok pendapatan petani $>50$ juta, konsumsi rata-rata sebesar Rp. 46.242.699,1 atau 46,67\%, investasi sebesar Rp. 27.309.599,67 atau $27,56 \%$ dan tabungan sebesar Rp. 25.532.689,2 atau 25,76\%.

Hasil penelitian ini menunjukan bahwa, besarnya pendapatan petani mempengaruhi alokasi pendapatan petani untuk konsumsi, investasi dan tabungan. Kelompok pendapatan petani yang lebih rendah yaitu $<50$ juta, investasi dan tabungan petani relative sedikit dikarenakan konsumsi yang tinggi, sedangkan kelompok pendapatan petani yang lebih besar yaitu $>50$ juta, pengeluaran untukkebutuhan konsumsi menurun sedangkan investasi dan tabungan bertambah.

\section{Saran}

Harga cengkeh yang fluktuatif memungkinkan pendapatan petani tidak selalu tinggi, untuk itu disarankan kepada petani untuk mengelolah keuangan dengan baik dengan menghindari sifat konsumtif, menambah kegiatan produksi yaitu dengan berinvestasi, serta menyisikan pendapatan untuk tabungan. Tujuanya Agar supaya petani akan lebih sejahtera dari sebelumnya.

\section{DAFTAR PUSTAKA}

Arifin, Zaenal, 2005. Teori Keuangan dan Pasar Modal, Ekonisia, Yogyakarta.

Gustiyana, H. 2004.Analisis Pendapatan Usahatani untuk Produk Pertanian Salemba empat: Jakarta.

Hermanto F. 1993. Ilmu Usaha Tani. Departemen Sosial Ekonomi. Bandung

Kadariah (1996) Pengantar Teori Ekonomi Makro, Bina Aksara, Jakarta

Kartaspoetra, AG. 1998. Pengantar Ekonomi Produksi Pertanian.PT. Bina Akasara. Jakarta

Kotler, P dan G. Amstrong, 2001. Prinsipprinsip pemasaran.Edisi kedelapan. Erlangga. Jakarta

Kusnadi. 1996. Kamus Istilah Pertanian. Erlangga. Yogyakarta. 
Mankiw, N. Gregory (2003) Teori Makroekonomi, Edisi Kelima, Erlangga, Jakarta.

Pangadaheng, Y. 2012. Analisis Pendapatan Petani kelapa di Kecamatan saliabu Kabupaten Talaud.Skripsi.Universitas Sam Ratulangi Manado.

Plantus. 2008. Syzygium aromaticum (Linn.) Merr. \& Perr. Cengkeh. Anekaplantasia.cybermediaclip.http://ane kaplanta.wordpress.com/2008/07/30/syzy gium-aromaticum - linn-merr-perrcengkeh. Diakses 20 januari 2015

Rahardja,P dan Manurung, M 2006. Teori Ekonomi Mikro. Fakultas ekonomi Universitas Indonesia, Jakarta

Rosydi, Suherman, 1996, Pengantar Teori Ekonomi, Raja Grafindo Persada, Jakarta.

Sukirno, Sadono 2000. Pengantar Teori Makroekonomi, Raja Grafindo Persada, Jakarta.

2012. Pengantar Teori Makroekonomi, Raja Grafindo Persada, Jakarta
Soekartawi. 1994. Pembanguna Pertanian. Rajagravindo Persada Jakarta. 1995. Analisis Usahatani. Penerbit Universitas Indonesia (UI-Press), Jakarta. 2002. Analisis Usahatani. Penerbit Universitas Indonesia (UI-Press), Jakarta

Suyanto Nurhadi, 2000. Ekonomi, Erlangga, Jakarta. 